\title{
A Measurement Framework for Knowledge-Based Economy (KBE) Efficiency in ASEAN: A Data Envelopment (DEA) Window Approach
}

\author{
Munshi Naser Ibne Afzal ${ }^{1} \&$ Roger Lawrey ${ }^{2}$ \\ ${ }^{1}$ Faculty of Business, Economics and Policy Studies, Universiti Brunei Darussalam, Jalan Tungku Link, Brunei \\ ${ }^{2}$ School of Accounting, Economics and Finance, University of Southern Queensland, Toowoomba Qld, Australia \\ Correspondence: Munshi Naser Ibne Afzal, Faculty of Business, Economics and Policy Studies, Universiti \\ Brunei Darussalam, Jalan Tungku Link, BE-1410, Brunei. Tel: 673-714-6601. E-mail: munshi.naser@gmail.com
}

Received: June 7, 2012 Accepted: August 1, 2012 Online Published: September 16, 2012

doi:10.5539/ijbm.v7n18p57 URL: http://dx.doi.org/10.5539/ijbm.v7n18p57

\begin{abstract}
The objective of this paper is to assess the relative efficiencies of ASEAN-5 countries in their development of knowledge-based economies (KBEs) during the period 2005-2010. The KBE concept was first used by the Organization for Economic Co-operation and Development (OECD) describing it as an economy which is directly based on the production, distribution and use of knowledge and information. Subsequently, the Asia Pacific Economic Cooperation forum (APEC) and the World Bank Institute (WBI), along with the OECD, extended the concept and developed frameworks to compare the status of the knowledge base of different economies. These frameworks identify four core dimensions: knowledge acquisition, production, distribution and utilization, and use many structural and qualitative variables in their analysis. But none of the current methodologies explicitly divide the KBE indicators under these four core dimensions or measure the efficiency with which knowledge inputs are transformed to knowledge outputs. This paper attempts to fill the gap in existing literature by building a policy-focused KBE framework, selecting appropriate indicators from the existing OECD and WBI KBE frameworks and assessing the relative input-output efficiencies of the ASEAN-5 countries in the development of their KBEs over time. For this purpose we use the linear programming application of Data Envelopment (DEA) Window Analysis. The DEA/Window scores allow the comparison of the relative performance of each country regarding each dimension of KBE. The importance of this study, however, is not so much the immediate result which highlights comparative efficiencies, but rather that DEA/Window is a workable model which can take the study of KBE further in investigating the contributory factors of KBE.
\end{abstract}

Keywords: knowledge-based economy, KBE frameworks, policy focused framework, ASEAN-5, OECD, APEC, WBI, DEA/Window

\section{Introduction}

The concept of the knowledge-based economy (KBE) was first introduced by the Organisation for Economic Co-operation and Development (OECD), defining it as an economy which is "directly based on the production, distribution and use of knowledge and information" (OECD, 1996). Subsequently, the Asia Pacific Economic Cooperation forum (APEC) $(2000,2004)$ and the World Bank Institute (WBI) (1999) referred to a KBE as an economy in which the production, distribution and use of knowledge is the main driver of growth, wealth creation and employment across all industries. These models or frameworks describe the environment necessary for the $\mathrm{KBE}$ and the indicators used to measure the various characteristics of the environment. While doing so, the OECD in its report on the Growth Project (OECD, 2001) emphasized the importance of a stable and open macroeconomic environment with effective functioning markets; diffusion of ICT; fostering innovation; development of human capital; and stimulating firm creation. Under these core KBE dimensions they proposed a large set of indicators (see Afzal and Lawrey 2012a). The World Bank Institute (1999) has developed the Knowledge Assessment Methodology (KAM) as a KBE framework for its member states in order to indicate their level of knowledge-based economic development and as a policy input to the achievement of sustainable economic growth. The WBI Knowledge Assessment Methodology (KAM) (www.worldbank.org/kam) is based on 83 structural and qualitative variables that serve as proxies for the four knowledge economy pillars: Overall Economic Performance (9), Economic Incentive and Institutional Regime Index (19), Innovation System Index 


\section{(24), Education and Human Resources Index (19) and ICT Index (12).}

These frameworks have one common trait in that they all give a basic description of the environment a KBE should possess and claim that a successful KBE should have four core dimensions, namely, knowledge acquisition, knowledge production, knowledge distribution and knowledge utilization. These KBE frameworks were developed to indicate the extent of countries' knowledge base and implicitly to guide policy. But they have little in theoretical underpinnings and applying them universally across all countries in different regions, at different stages of development and with different institutional, social and economic characteristics may be misleading and result in inappropriate policy responses. In an earlier paper we proposed a framework that clearly distinguishes input-output indicators of a knowledge-based economy under the four core dimensions and attempted to adapt them in a practical policy oriented way for an economy that was attempting to transform from a resource-based to a knowledge-based economy (Afzal and Lawrey 2012a, see also Lee, 2001; Tan, Hooy, Manzoni \& Islam 2008 and Karahan, 2011). In a subsequent paper we used the Beta coefficient technique to rank the most important KBE input factors to KBE output factors and examine why the resultant ranking varies across the ASEAN-5 countries namely Indonesia, Malaysia, Singapore, the Philippines and Thailand (Afzal and Lawrey 2012b).

This paper extends previous research by assessing the relative efficiencies with which the ASEAN-5 countries transform KBE inputs into KBE outputs over time using Data Envelopment (DEA) Window Analysis. DEA/window analysis has been widely used to assess the operational efficiencies where traditional measures have been found wanting (Tan et al., 2008). Some examples of DEA/Window analysis include: measuring sea port efficiencies (Eraqi et al., 2010, Cullinane et al., 2004), banking group efficiencies (Sufian, 2007, Al-Delaimi and Al-Ani, 2006), and other industries e.g. wood, holding companies, science park (Hemmasi et at., 2011, Sun, 2011). However, the approach is not yet widely applied at country knowledge economy assessment levels although Tan et al., (2008) used DEA cross-sectional analysis in the Asia-pacific region to measure knowledge economies ranking. Measuring efficiencies of countries by cross-sectional analysis is static analysis rather than the investigation of dynamic changes in efficiencies analysed in this paper.

This paper is organized as follows. Section 2 discuss the research framework, Section 3 describes the DEA/Window methodology and the differences between traditional regression analysis and DEA. The empirical results are presented and discussed in Section 4 and Section 5 considers policy implications and gives concluding remarks.

\section{Research Design}

\subsection{Research Framework}

This research attempts to measure the performance of the ASEAN-5 countries for the period 2005-2010 using secondary data from World Development Indicators (WDI)-2010, World Competitiveness Yearbook (WCY)-2011 and ASEAN HQ in Indonesia. The ASEAN economies, particularly the ASEAN-5 (Indonesia, Malaysia, The Philippines, Singapore and Thailand, the first founder members) have been pursuing export-led and foreign direct investment-led development strategies for several years. In earlier decades, the economic development of the ASEAN-4 (excluding Singapore) was largely resource-based as exporters of both agricultural and mineral primary products. But particularly after the slowdown of economic growth during the late 1990s knowledge based growth has been pursued as a development policy option for long run, sustainable growth. If policy is to be directed to KBE, the efficiency with which inputs are transformed to outputs will be an important input to informed policy making.

\subsubsection{A Policy Focused KBE Framework}

From the OECD core definition of KBE, we build a policy-focused KBE framework considering four knowledge dimensions under which there are four output variables. The output variables are real GDP growth for knowledge acquisition, scientific and technical journal articles per 1000 population for knowledge production, computer users per 1000 population for knowledge distribution and high-tech exports as a percentage of total manufacturing exports for the knowledge utilization dimension. The KBE input variables are selected by observing time series data availability and would preferably be available for all relevant countries, for the purposes of comparison (ABS, 2002; Afzal \& Lawrey, 2012a).

Table 1 shows our policy-focused KBE framework for window analysis. 
Table 1. Policy-focused KBE framework

\begin{tabular}{|c|c|c|c|c|}
\hline Dimensions & Knowledge acquisition & Knowledge production & Knowledge distribution & Knowledge utilization \\
\hline Input & $\begin{array}{l}\text { 1.Openness=(Exports }+ \\
\text { imports)/GDP } \\
\text { 2. FDI inward flows } \\
\text { as \% GDP } \\
\text { 3. Legal and regulatory } \\
\text { quality } \\
\text { 4. Transparency }\end{array}$ & $\begin{array}{l}\text { 1.Scientific R \& D } \\
\text { expenditure as \% } \\
\text { GDP } \\
\text { 2.Intelectual Property } \\
\text { Rights (IPR) }\end{array}$ & $\begin{array}{l}\text { 1. Education } \\
\text { expenditure as \% } \\
\text { GDP } \\
\text { 2. Net enrolment ratio } \\
\text { at secondary school }\end{array}$ & $\begin{array}{l}\text { 1. Knowledge Transfer } \\
\text { rate (university to } \\
\text { industry) } \\
\text { 2.FDI inflows \% of } \\
\text { GDP }\end{array}$ \\
\hline Output & Real GDP growth & $\begin{array}{l}\text { Scientific publications } \\
\text { per } 1000 \text { population }\end{array}$ & $\begin{array}{l}\text { PC penetration per } \\
1,000 \text { population }\end{array}$ & $\begin{array}{l}\text { High-tech export \% } \\
\text { of Total export }\end{array}$ \\
\hline
\end{tabular}

Figure 1 shows the summary of our research framework:

Select KBE input variables from the available large set of KBE variables proposed by different organizations (OECD, APEC, WBI, and ABS) according to time series data availability and relevance.

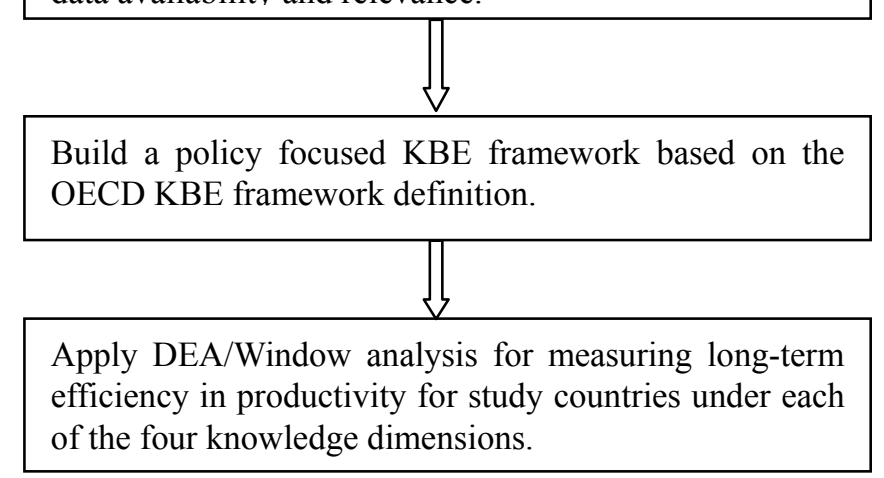

Figure 1. Three steps in our research framework

\section{DEA/Window Analysis Methodology}

\subsection{Data Envelopment Analysis (DEA)}

Data Envelopment Analysis (DEA) is a methodology based upon an application of linear programming. It was originally developed for performance measurement. It has been successfully employed for assessing the relative performance or technical efficiency of a set of firms that use a variety of identical inputs to produce a variety of identical outputs. The principles of DEA date back to Farrel (1957). The recent series of discussions on this topic started with the article by Charnes, Cooper and Rhodes (1978). A good introduction to DEA is available in Norman and Stoker (1991). Cooper, Seiford and Tone (2000) provide recent and comprehensive material on DEA (Ramanathan, 2003). DEA is a non-parametric approach that calculates an efficiency level by conducting linear programming for each unit in the sample. It measures the efficiency of the Decision Making Units (DMU) by the comparison with the best producer in the sample to derive relative efficiency.

A distinctive feature of the DEA approach is that, for each DMU (e.g. an individual country), it calculates a single relative ratio by comparing total weighted outputs to total weighted inputs for each unit without requiring the proposition of any specific functional form. Accordingly, the DEA efficiency value has an upper bound of one and a lower bound of zero. Two types of DEA models, namely the input-oriented and the output-oriented models, have been widely articulated by operational researchers. Though the input-oriented model focuses on cost minimization while the output-oriented model focuses on the output maximization, evidence indicates that research results are not sensitive to which of the models is being used (Hsu, Luo and Chao, 2005). In the application of DEA, a linear programming model needs to be formulated and solved for each DMU. Such a requirement makes the calculation of efficiency scores for all of the studied countries a tedious job, but by using software such as IDEAS, DEA-Solver or EMS, efficiency scores for all DMUs in one DEA model can be found 
easily. In addition to countries, DMUs can include manufacturing units, departments of big organizations such as universities, schools, bank branches, hospitals, power plants, police stations, tax offices, prisons, and defence bases, a set of firms or even practising individuals such as medical practitioners. Recently this method was used for measuring the efficiencies of knowledge economies in a cross sectional study (Tan et al., 2008).

\subsubsection{Theoretical Construction of the DEA System}

As we have seen, DEA is based on technical efficiency (TE) or performance efficiency, which can be shown as:

$\mathrm{WO}=$ weighted output, $\mathrm{WI}=$ weighted input

$$
\text { Technical efficiency (TE) }=\frac{\sum W O}{\sum W T}
$$

Mathematically we can express the above relation by the following formula:

$$
\mathrm{E}_{\mathrm{k}}=\frac{\sum_{j=1}^{M} U_{j} O_{j k}}{\sum_{i=1}^{N} V_{i} I_{i k}}
$$

$\mathrm{E}_{\mathrm{k}}=\mathrm{TE}$ for the $\mathrm{DMU}_{\mathrm{k}}$ (between 0 and 1)

$\mathrm{K}=$ Number of $\mathrm{DMU}_{\mathrm{k}}$, in the sample

$\mathrm{N}=$ Number of inputs used $(\mathrm{i}=1, \mathrm{~L}, \mathrm{~N})$

$\mathrm{M}=$ Number of outputs $(\mathrm{j}=1, \mathrm{~L}, \mathrm{M})$

$\mathrm{O}_{\mathrm{jk}}=$ The observed level of output $\mathrm{j}$ from $\mathrm{DMU}_{\mathrm{k}}$

$I_{i k}=$ The observed level of input $i$ from $\mathrm{DMU}_{\mathrm{k}}$

$\mathrm{V}_{\mathrm{i}}=$ The weight of input $\mathrm{i}$

$\mathrm{U}_{\mathrm{j}}=$ The weight of output $\mathrm{j}$

To measure $\mathrm{TE}_{\mathrm{k}}$ for $\mathrm{DMU}_{\mathrm{k}}$ by using linear programming the following problem must be solved which is MaxTE

Subject to $\mathrm{E}_{\mathrm{k}} \leq 1, \mathrm{k}=1,2, \mathrm{~L}, \mathrm{~K}$

Where $\mathrm{TE}_{\mathrm{k}}$ is either maximizing outputs from given inputs or minimizing inputs for a given level of output. The above problem cannot be solved as stated because of difficulties associated with nonlinear (fractional) mathematical programming. Charnes, Cooper and Rhodes (1978) have developed a mathematical transformation which converts the above nonlinear programming to linear one as follows:

$$
\begin{gathered}
\operatorname{Max} \sum_{j=1}^{M} U_{j} O_{j k} \\
\text { S.t. } \\
\sum_{i=1}^{N} V_{i} I_{i k}=1 \\
\sum_{j=1}^{M} U_{j} O_{j k} \leq \sum_{i=1}^{N} V_{i} I_{i k} \\
\mathrm{U}_{\mathrm{j}}, \mathrm{V}_{\mathrm{i}} \geq>0 \\
>0
\end{gathered}
$$

The above procedure can be done also by using input weights $V_{i}$ and variable $I_{i k}$ in place of $U_{j} O_{j k}$ and subject to an output constraint. As a whole, the optimization procedure in DEA ensures that the particular DMU, in our study the country, being evaluated is given the highest score possible by maximizing its relative efficiency ratio, at the same time maintaining equity for all other DMUs. DEA establishes relative efficiency scores led by the benchmark of unity as the highest score possible for one or more DMUs. It other words, the most efficient DMUs may score unity while others can have a value below this or zero (Tan et al., 2008). Cooper et al. (2000) mentions DEA constructs a non-parametric envelop frontier over the data points to identify DMUs that lie on the 
efficiency frontier and for those that do not, how far they are from this frontier at their nearest point. Hence, it allows the simultaneous analysis of multiple outputs and multiple inputs, it does not require an explicit a priori determination of a production function i.e. is no need for defining a functional relationship between inputs and outputs and it does not require information on prices. Therefore DEA is suitable for measuring the efficiency of our study countries in this paper. Basic conditions that are important in using DEA are as follows:

1) Positive values: generally, the DEA formulation requires that the input and output variables be positive (greater than zero)

2) Isotinicity: it is required that the functions relating inputs to outputs have a property called isotonicity which means that an increase in any input results in some output increase and not a decrease in any output.

3) A general rule that three DMUs are required for input and output variables used in the model in order to insure sufficient degrees of freedom for a meaningful analysis.

4) Homogeneity of DMUs: DEA requires a relatively homogenous set of entities. That is all entities included in the evaluation set should have the same inputs and outputs in positive amounts.

5) Control of weights: The weights $U_{j}$ and $V_{i}$ are determined while solving the DEA model. These weights are computed in such that a way the organization under evaluation is placed in the best light possible to the other units in the data set.

\subsection{DEA/Window Analysis}

The concept of DEA/Window analysis is due to G. Klopp (1985) who developed the technique in his capacity as chief statistician for the U.S. Army Recruiting Command. Later Window Analysis was proposed formally by Charnes, Clark, Charles, Cooper, Boaz and Golany (1985) as a time dependent version of DEA analysis. In order to capture the variations of efficiency over time, Charnes et al. (1985) proposed this technique in his study. Window analysis generally assesses the performance of a DMU over time by treating it as a different entity in each period. This method allows for tracking the performance of a unit or a process.

The basic idea is to look at each DMU as if it were a different unit in each of the reporting dates. Then each DMU is not necessarily compared with the whole data set, but instead only with alternative subsets of panel data. Most DEA analysis is handled on the basis of cross-sectional analysis which usually evaluates DMU efficiency, a stationary factor. However, this seems to be a weak point of DEA analysis. To supplement this weak point, the DEA/window analysis approach was developed (Park et al. 2011). DEA/Window ideally follows the moving average concept where, given a series of numbers and a fixed subset size, the first element of the moving average is obtained by taking the average of the initial fixed subset of the number series. Then the subset is modified by "shifting forward", that is excluding the first number of the series and including the next number following the original subset in the series. This creates a new subset of numbers, which is averaged. This process is repeated over the entire data series.

The DEA/Window approach considers trend, stability, and seasonal behaviour. In general, when the total period of data collected for DEA/Window analysis is ' $\mathrm{S}$ ' and window range is ' $\mathrm{R}$ ' then the number of windows are as follows, $\mathrm{w}=\mathrm{S}-\mathrm{R}+1$ (Cooper et al., 2000). In our case we have 6 years (2005-2010) and window range is 3 , therefore we have 4 windows for each country in each knowledge dimensions.

\section{Empirical Results and Discussion}

DEA/window analysis can be conducted using a variety of different software. In this study we use Efficiency Measurement System (EMS) software, version 1.3 developed by Holger Scheel in 2000. This study assumes constant returns to scale; that is, as all inputs double, all outputs will double. The window analysis enables us to identify the best and the worst performing countries in a relative sense. The overall efficiency for each DMU (country) is calculated by adopting the original CCR model prepared by Charnes, Cooper and Rhodes (explained in sub-section 3.1.1). Subsequently the DEA/window analysis is applied for finding, over time, the trend and stability of efficiencies. Based on the rule of thumb of DEA, the number of DMUs should be greater than double of the sum of inputs and outputs. Therefore we add South Korea, a member of ASEAN plus three countries, to make the analysis robust. In addition to the efficiency analysis we calculate mean, standard deviation and coefficient of variation for each window. The study countries are compared on the basis of average efficiency i.e. mean and coefficient of variation (C.V.). We use this C.V. technique for comparison because the C.V. aims to describe the dispersion of the variable in a way that does not depend on the variable's measurement unit. Usually the standard formulation of the C.V. is the ratio of the standard deviation to the mean. The lower the C.V., the smaller the dispersion relative to the predicted mean value and this is suggestive of a better result in comparison of higher C.V values. 
The results will follow the sequence of our policy-focused KBE framework and all values are shown in percentage points i.e. the efficiency will vary from $0-100 \%$ according to the DEA condition.

Table 2. Knowledge acquisition dimension

\begin{tabular}{|c|c|c|c|c|c|c|c|c|c|}
\hline & 2005 & 2006 & 2007 & 2008 & 2009 & 2010 & Mean & S.D & C.V \\
\hline Indonesia & 99.99 & 95.38 & 100 & & & & 98.45 & 2.66 & .027 \\
\hline Indonesia & & 95.38 & 100 & 94.19 & & & 96.52 & 3.06 & .031 \\
\hline Indonesia & & & 100 & 94.19 & 98.17 & & 97.45 & 2.97 & 0.03 \\
\hline \multirow{2}{*}{ Indonesia } & & & & 92.69 & 94.21 & 100 & 95.63 & 3.8 & 0.04 \\
\hline & & & & & & Average $=$ & 97.63 & 3.12 & 0.032 \\
\hline Malaysia & 31.99 & 31.87 & 34.16 & & & & 32.67 & 1.2 & 0.039 \\
\hline Malaysia & & 31.87 & 34.16 & 27.68 & & & 31.23 & 3.2 & 0.105 \\
\hline Malaysia & & & 34.21 & 27.83 & 14.25 & & 25.43 & 10.19 & 0.40 \\
\hline \multirow[t]{2}{*}{ Malaysia } & & & & 26.71 & 12.07 & 43.17 & 27.31 & 15.55 & 0.56 \\
\hline & & & & & & Average $=$ & 29.16 & 7.5 & 0.27 \\
\hline Philippines & 54.18 & 53.78 & 82.99 & & & & 63.65 & 16.75 & 0.26 \\
\hline Philippines & & 53.78 & 82.99 & 54.02 & & & 63.59 & 16.79 & 0.26 \\
\hline Philippines & & & 83.13 & 54.65 & 16.07 & & 51.28 & 33.65 & 0.65 \\
\hline \multirow[t]{2}{*}{ Philippines } & & & & 49.54 & 15.11 & 99.09 & 54.58 & 42.21 & 0.77 \\
\hline & & & & & & Average $=$ & 58.27 & 27.35 & 0.48 \\
\hline Singapore & 18.49 & 21.17 & 21.57 & & & & 20.41 & 1.67 & 0.082 \\
\hline Singapore & & 21.17 & 21.57 & 4.39 & & & 15.71 & 9.80 & 0.62 \\
\hline Singapore & & & 21.57 & 4.42 & 2.14 & & 9.37 & 10.62 & 1.13 \\
\hline \multirow[t]{2}{*}{ Singapore } & & & & 4.12 & 2.14 & 38.93 & 15.06 & 20.69 & 1.37 \\
\hline & & & & & & Average $=$ & 15.13 & 10.69 & 0.80 \\
\hline Thailand & 33.18 & 36.48 & 36.64 & & & & 35.43 & 1.95 & 0.055 \\
\hline Thailand & & 36.48 & 34.64 & 18 & & & 29.70 & 10.17 & 0.34 \\
\hline Thailand & & & 34.64 & 18.05 & 22.12 & & 24.93 & 8.62 & 0.34 \\
\hline \multirow[t]{2}{*}{ Thailand } & & & & 17.82 & 20.91 & 69.09 & 35.94 & 28.75 & 0.79 \\
\hline & & & & & & Average $=$ & 31.5 & 12.37 & 0.38 \\
\hline Korea & 73.01 & 100 & 100 & & & & 91.0 & 15.58 & 0.171 \\
\hline Korea & & 100 & 100 & 40.97 & & & 80.32 & 34.08 & 0.42 \\
\hline \multirow[t]{2}{*}{ Korea } & & & 100 & 41.53 & 5.83 & & 49.12 & 47.54 & 0.96 \\
\hline & & & & & & Average $=$ & 66.81 & 36.41 & 0.64 \\
\hline
\end{tabular}

The first result of the DEA calculations, whether cross-section or window analysis, is an efficiency rating of each observation by country. A rating of $100 \%$ indicates that the country is located on the efficiency frontier. An efficiency rating less than $100 \%$ signals non-optimal behaviour. In our analysis, we show efficiencies of the countries in each time period window. We are, however, interested to analyse the study countries on the basis of the average efficiency (mean) over multiple time-periods and their corresponding C.V. values in each KBE dimension.

The results of knowledge acquisition dimension are shown in Table 2. Observing the average efficiency values from the table, Indonesia has the highest mean of $97.63 \%$ and lowest C.V value of 0.032 compared to the other five countries. This indicates that Indonesia is the best performer in the knowledge acquisition dimension during the relevant time period. This can be explained in two different ways. First of all, the highest mean and lowest C.V values of Indonesia suggest that most of the knowledge stock and flows of Indonesia depends on FDI and openness. The country is making good use of these two input factors for generating economic growth. On the other hand, it also implies that Indonesian domestic knowledge workers are not skilled enough to contribute to economic growth by using indigenous knowledge stock or flows. Researchers have found that a critical mass of human capital has not been achieved by Indonesia compared to other big ASEAN economies (Tjakraatmadja et al., 2011). Other countries in this region, especially Singapore, S. Korea, Malaysia and Thailand are utilizing 
their domestic knowledge workers to accelerate economic growth compared to Indonesia in this time period. Therefore we can say that Indonesia is heavily dependent on foreign assistance in order to acquire knowledge and generate economic growth.

Table 3 shows the results of the knowledge production dimension. In this case, Thailand scores the highest mean value $91.09 \%$ followed by South Korea $70.87 \%$ and Singapore $44.37 \%$. In this dimension this study considers R\&D expenditure and the extent to which intellectual property rights are adequately enforced (WCY-2011, IMD WCY executive survey based on an index from 0 to 10) as input variables and scientific and technical journal articles per 1000 people as the output variable. However, According to World Development Indicators (WDI) 2010 data, Singapore R\&D expenditure as a percentage of GDP was the highest 3.21\% compared to Indonesia $0.08 \%$, Malaysia $0.88 \%$, the Philippines $0.12 \%$ and Thailand $0.24 \%$. In addition to this, Singapore in 2010 produced 3901.6 original scientific articles compared to Indonesia 200.1, Malaysia 880, the Philippines 197 and Thailand 1827 (WDI-2010). The raw data indicates Singapore as a better performer compare to other ASEAN countries though our efficiency analysis shows Thailand is the most efficient country. This is due to the reason of the weights that DEA Window analysis take into account for efficiency measurement. Therefore we can say there is a clear distinction between looking at the raw data and DEA Window analysis to measure a country's performance. This is an example in the case of Thailand.

Table 3. Knowledge production dimension

\begin{tabular}{lccccccccc}
\hline & 2005 & 2006 & 2007 & 2008 & 2009 & 2010 & Mean & S.D & C.V \\
\hline Indonesia & 49.88 & 43.58 & 30.01 & & & & 41.15 & 10.15 & 0.24 \\
Indonesia & & 43.58 & 30.01 & 34.73 & & & 36.10 & 6.8 & 0.19 \\
Indonesia & & & 30.01 & 34.73 & 34.57 & & 33.10 & 2.6 & 0.08 \\
Indonesia & & & & 36.53 & 36.37 & 32.09 & 34.99 & 2.51 & 0.07 \\
& & & & & & Average $=$ & 36.33 & 5.51 & 0.14 \\
Malaysia & \multirow{2}{*}{14.58} & 15.97 & 18.97 & & & & 16.50 & 2.24 & 0.13 \\
Malaysia & & 15.97 & 18.97 & 16.48 & & & 17.14 & 1.60 & 0.09 \\
Malaysia & & & 19.13 & 16.72 & 14.46 & & 16.77 & 2.33 & 0.13 \\
Malaysia & & & & 31.60 & 31.25 & 31 & 31.28 & 0.30 & 0.009 \\
& & & & & & Average $=$ & 20.42 & 1.61 & 0.08 \\
Philippines & 18.02 & 21.85 & 21.53 & & & & 20.46 & 2.12 & 0.10 \\
Philippines & & 21.85 & 21.53 & 23.77 & & & 22.38 & 1.21 & 0.05 \\
Philippines & & & 21.53 & 23.77 & 23.82 & & 23.04 & 1.30 & 0.056 \\
Philippines & & & & 25.01 & 25.06 & 20.99 & 23.68 & 2.33 & 0.098 \\
& & & & & & Average $=$ & 22.39 & 1.74 & 0.07 \\
Singapore & 26.40 & 28.21 & 25.62 & & & & 26.74 & 1.32 & 0.04 \\
Singapore & & 28.21 & 25.62 & 23.14 & & & 25.65 & 2.53 & 0.09 \\
Singapore & & & 26.32 & 23.79 & 27.54 & & 25.88 & 1.91 & 0.07 \\
Singapore & & & & 97.67 & 100 & 100 & 99.22 & 1.34 & 0.01 \\
& & & & & & Average $=$ & 44.37 & 1.7 & 0.05 \\
Thailand & \multirow{2}{*}{66} & 76.24 & 100 & & & & 80.74 & 17.44 & 0.21 \\
Thailand & & 76.24 & 100 & 95.06 & & & 90.43 & 12.53 & 0.13 \\
Thailand & & & 100 & 95.06 & 87.29 & & 94.11 & 6.40 & 0.06 \\
Thailand & & & & 100 & 97.26 & 100 & 99.08 & 1.58 & 0.01 \\
& & & & & & Average $=$ & 91.09 & 9.48 & 0.1 \\
Korea & 97.90 & 100 & 99.74 & & & & 99.21 & 1.14 & 0.011 \\
Korea & & 100 & 99.74 & 10.69 & & & 70.14 & 51.48 & 0.7 \\
Korea & & & 100 & 10.72 & 9.68 & & 40.13 & 51.84 & 1.29 \\
Korea & & & & 81.29 & 70.12 & 70.64 & 74.01 & 6.30 & 0.08 \\
& & & & & & Average $=$ & 70.87 & 27.6 & 0.5 \\
\hline
\end{tabular}


Table 4 reveals the knowledge distribution dimension window results. In this table, Singapore scores the highest mean $95.86 \%$ and the lowest value of C.V, which is the best result compared to other ASEAN members. Here, we use education expenditure as a percentage of GDP and secondary school enrolment as a percentage of total enrolment as input variables and computer users per 1000 population as the output variable. Singapore has the highest numbers of computers users at 827.48 per thousand populations compared to Indonesia 42.51, Malaysia 337, the Philippines 81.12 and Thailand 122.61 in 2010 (WDI-2010, WCY-2011). Moreover, Singapore's education expenditure as a percentage of GDP, and secondary school enrolment ratio are historically high in ASEAN (Heng et al., 2000). This high performance of input-output KBE indicators results in Singapore ranking first in the knowledge distribution dimension. S. Korea is the second best performer in this dimension having a $92.44 \%$ mean and 0.05 C.V value.

Table 4. Knowledge distribution dimension

\begin{tabular}{|c|c|c|c|c|c|c|c|c|c|}
\hline & 2005 & 2006 & 2007 & 2008 & 2009 & 2010 & Mean & S.D & C.V \\
\hline Indonesia & 7.58 & 6.75 & 8.49 & & & & 7.60 & 0.87 & 0.11 \\
\hline Indonesia & & 6.75 & 8.49 & 11.97 & & & 9.07 & 2.65 & 0.29 \\
\hline Indonesia & & & 8.02 & 11.31 & 9.84 & & 9.72 & 1.64 & 0.16 \\
\hline \multirow[t]{2}{*}{ Indonesia } & & & & 10.88 & 9.47 & 11.06 & 10.47 & 0.87 & 0.083 \\
\hline & & & & & & Average $=$ & 9.21 & 1.49 & 0.12 \\
\hline Malaysia & 45.11 & 49.52 & 55.22 & & & & 49.95 & 5.06 & 0.10 \\
\hline Malaysia & & 46.30 & 51.62 & 56.04 & & & 51.32 & 4.87 & 0.09 \\
\hline Malaysia & & & 46.04 & 49.97 & 53.54 & & 49.85 & 3.75 & 0.07 \\
\hline \multirow[t]{2}{*}{ Malaysia } & & & & 48.29 & 51.73 & 55.62 & 51.88 & 3.66 & 0.07 \\
\hline & & & & & & Average $=$ & 50.75 & 4.3 & 0.08 \\
\hline Philippines & 10.11 & 11.83 & 13.53 & & & & 11.82 & 1.71 & 0.14 \\
\hline Philippines & & 11.30 & 12.91 & 14.94 & & & 13.05 & 1.82 & 0.13 \\
\hline Philippines & & & 11.25 & 12.79 & 13.99 & & 12.67 & 1.37 & 0.10 \\
\hline \multirow[t]{2}{*}{ Philippines } & & & & 12.36 & 13.52 & 15.13 & 13.67 & 1.39 & 0.10 \\
\hline & & & & & & Average $=$ & 12.80 & 1.57 & 0.11 \\
\hline Singapore & 93.20 & 95.90 & 100 & & & & 96.36 & 3.42 & 0.035 \\
\hline Singapore & & 93.38 & 100 & 100 & & & 97.79 & 3.82 & 0.035 \\
\hline Singapore & & & 94.44 & 90.13 & 100 & & 94.85 & 4.94 & 0.052 \\
\hline \multirow[t]{2}{*}{ Singapore } & & & & 86.76 & 96.63 & 100 & 94.46 & 6.88 & 0.07 \\
\hline & & & & & & Average $=$ & 95.86 & 4.76 & 0.04 \\
\hline Thailand & 12.89 & 16.97 & 18.07 & & & & 15.97 & 2.7 & 0.17 \\
\hline Thailand & & 15.86 & 16.89 & 18.27 & & & 17.0 & 1.2 & 0.07 \\
\hline Thailand & & & 15.07 & 16.29 & 18.31 & & 16.55 & 1.6 & 0.09 \\
\hline \multirow[t]{2}{*}{ Thailand } & & & & 15.74 & 17.69 & 19.65 & 17.69 & 1.9 & 0.11 \\
\hline & & & & & & Average $=$ & 16.80 & 1.85 & 0.10 \\
\hline Korea & 88.95 & 94.45 & 100 & & & & 94.46 & 5.5 & 0.05 \\
\hline Korea & & 89.01 & 95.14 & 100 & & & 94.71 & 5.5 & 0.05 \\
\hline Korea & & & 83.37 & 89.18 & 94.90 & & 89.15 & 5.7 & 0.06 \\
\hline \multirow[t]{2}{*}{ Korea } & & & & 86.17 & 91.70 & 96.48 & 91.45 & 5.15 & 0.05 \\
\hline & & & & & & Average $=$ & 92.44 & 5.46 & 0.05 \\
\hline
\end{tabular}


Finally, in Table 5 we present the results of the knowledge utilization dimension.

Table 5. Knowledge utilization dimension

\begin{tabular}{|c|c|c|c|c|c|c|c|c|c|}
\hline & 2005 & 2006 & 2007 & 2008 & 2009 & 2010 & Mean & S.D & C.V \\
\hline Indonesia & 31.05 & 27.11 & 18.63 & & & & 25.59 & 6.34 & 0.2 \\
\hline Indonesia & & 25.33 & 17.53 & 17.56 & & & 20.14 & 4.49 & 0.2 \\
\hline Indonesia & & & 17.53 & 17.56 & 25.35 & & 20.14 & 4.45 & 0.2 \\
\hline \multirow[t]{2}{*}{ Indonesia } & & & & 17.11 & 23.71 & 20.47 & 20.43 & 3.3 & 0.1 \\
\hline & & & & & & Average $=$ & 21.57 & 4.64 & 0.17 \\
\hline Malaysia & 75.22 & 56.06 & 52.47 & & & & 61.25 & 12.23 & 0.19 \\
\hline Malaysia & & 56.06 & 52.47 & 44.09 & & & 50.87 & 6.14 & 0.12 \\
\hline Malaysia & & & 52.47 & 44.09 & 73.88 & & 56.81 & 15.36 & 0.27 \\
\hline \multirow[t]{2}{*}{ Malaysia } & & & & 42.97 & 73.88 & 42.50 & 53.11 & 17.98 & 0.33 \\
\hline & & & & & & Average $=$ & 55.51 & 12.92 & 0.2 \\
\hline Philippines & 100 & 90.12 & 100 & & & & 96.70 & 5.7 & 0.05 \\
\hline Philippines & & 90.12 & 100 & 100 & & & 96.70 & 5.7 & 0.05 \\
\hline Philippines & & & 100 & 100 & 95.78 & & 98.59 & 2.4 & 0.02 \\
\hline \multirow[t]{2}{*}{ Philippines } & & & & 100 & 90.26 & 100 & 96.75 & 5.6 & 0.05 \\
\hline & & & & & & Average $=$ & 97.18 & 4.85 & 0.04 \\
\hline Singapore & 55.97 & 52.93 & 40.68 & & & & 49.86 & 8.09 & 0.16 \\
\hline Singapore & & 52.93 & 40.68 & 45.21 & & & 46.27 & 6.19 & 0.13 \\
\hline Singapore & & & 40.68 & 45.21 & 44.22 & & 43.37 & 2.38 & 0.05 \\
\hline \multirow[t]{2}{*}{ Singapore } & & & & 44.06 & 43.10 & 43.67 & 43.61 & 0.48 & 0.01 \\
\hline & & & & & & Average $=$ & 45.77 & 4.2 & 0.06 \\
\hline Thailand & 39.35 & 38.37 & 45.01 & & & & 40.91 & 3.58 & 0.08 \\
\hline Thailand & & 38.37 & 45.01 & 36.36 & & & 39.91 & 4.52 & 0.11 \\
\hline Thailand & & & 45.01 & 36.36 & 38.47 & & 39.94 & 4.51 & 0.11 \\
\hline \multirow[t]{2}{*}{ Thailand } & & & & 35.44 & 36.87 & 36.48 & 36.26 & 0.73 & 0.02 \\
\hline & & & & & & Average $=$ & 39.25 & 3.33 & 0.07 \\
\hline Korea & 72.23 & 95.67 & 100 & & & & 89.3 & 14.9 & 0.16 \\
\hline Korea & & 81.74 & 100 & 89.73 & & & 90.49 & 9.15 & 0.10 \\
\hline Korea & & & 100 & 84.93 & 100 & & 94.97 & 8.7 & 0.09 \\
\hline \multirow[t]{2}{*}{ Korea } & & & & 84.93 & 100 & 97.11 & 94.01 & 7.9 & 0.08 \\
\hline & & & & & & Average $=$ & 92.19 & 10.16 & 0.10 \\
\hline
\end{tabular}

In Table 5, the Philippines' has the highest mean of $97.18 \%$ and the lowest C.V value in the knowledge utilization dimension. This indicates that the Philippines' is the best performer in this dimension. We use FDI inflows as a percentage of GDP and knowledge transfer rate from university to industry (WCY-2011 executive survey based on an index from 0 to 10) as input variables and high-tech exports as a percentage of total manufacturing exports as the output variable. The Philippines had the largest share of high-tech exports as a percentage of total manufacturing exports in 2010. Its percentage of high-tech products as a percentage of total manufacturing exports was $65.65 \%$ followed by Singapore $50.01 \%$, Malaysia $48.11 \%$, Indonesia $13.13 \%$ and Thailand $27.12 \%$ in the same year (WDI-2010). This implies that the Philippines is making good use of its education expenditure in order to produce new knowledge and ideas in the universities that eventually transfer 
this knowledge to high-tech industrial growth. The research firm the Meta Group ranked the Philippines number one in the world in terms of knowledge workers (http://www.slcv.edu.ph/news/news7-03.htm). Its Cyber Atlas of 2000 put the Philippines ahead of 47 other countries, including the United States, Australia, France, Canada, and India. Currently the Philippines is the largest exporter of semi-conductors in the world and Japan is the number one buyer of these high-tech products from the Philippines (Lall, 2000). South Korea is the next best performer having average efficiency of $92.19 \%$ in the knowledge utilization dimension. Information and communication products, electronic goods, pharmaceutical and bio-tech products are considered high-tech export goods in this region.

\section{Conclusion and Policy Recommendations}

The results of our analysis have interesting policy implications for promoting KBE in ASEAN. We wish to stress here that findings of the study are critically based on the choice of KBE variables, and hence, the policy implications discussed here should be considered within this perspective. This study analyses the performance efficiencies in four knowledge dimensions of the ASEAN-5 economies for the period 2005-2010. The study has indicated how the use of DEA/window analysis can identify how individual countries' performance varies in different knowledge dimensions over time. This approach is advocated over the commonly used cross-sectional DEA analysis. Observing the average efficiency (mean) and the coefficient of variation values (C.V.) of DEA/Window analysis in four knowledge dimensions, firstly, we find Indonesia is the highest mean $97.63 \%$ and lowest C.V. value of 0.032 compare to other ASEAN members in knowledge acquisition dimension. This implies Indonesia is the best performer in this dimension, using FDI inflows and trade openness for generating high economic growth, but with underutilized domestic knowledge stocks and flows. In the case of knowledge production and distribution, our results show that Thailand and Singapore is the best performer respectively compared to other ASEAN countries. This implies that the highly productive domestic knowledge workers of Thailand and Singapore are making best use of their R\&D expenditure to produce new ideas, knowledge and innovations. In knowledge utilization, the Philippines' is the best performer compared to other ASEAN members. In fact the Philippines' scores the highest mean efficiency $97.18 \%$ and the lowest C.V. value 0.04 in ASEAN from our analysis. The reason behind this success of the Philippines is its deep skilled human resources pool. The Philippines has a 94\% literacy rate and a large pool of college students. It also has good English proficiency, being the third largest English speaking nation in the world. In Asia, the country's supply of IT workers is second only to that of India, which has a population of over one billion. The findings of this study suggest that in order to become a successful KBE, Indonesia should invest more on knowledge production, distribution and utilization. Singapore should consider the knowledge utilization dimension as a future investment sector. The Philippines prime focus should be on how to make more use of the knowledge acquisition, production and distribution dimensions in order to sustain their advances in knowledge utilization. Finally, a balanced development in all four knowledge dimensions for Malaysia, South Korea and Thailand is required for them to become efficient performers in KBE.

This research, while evaluating the relative efficiency scores using DEA/Window analysis did not restrict any input or output weights. This may affect the results if certain input or output measures are more important than others. In future research, it may be interesting to identify such weights to reflect relative importance and integrate them into the analysis.

\section{References}

Afzal, M. N. I., \& Lawrey, R. (2012a). KBE frameworks and their applicability to a resource-based country: The case of Brunei Darussalam. Asian Social Science, 8(7), 208-218.

Afzal, M. N. I., \& Lawrey, R. (2012b). Knowledge-based economy (KBE) frameworks and empirical investigation of KBE input-output indicators for ASEAN. International Journal of Economics and Finance, 4(9), 13-22.

Al-Eraqi, A. S., Mustafa, A., \& Khader, A. T. (2010). An extended DEA windows analysis: Middle East and East $\begin{array}{lllll}\text { African seaports. Journal of Economic } & \text { Studies, } & 37(2), & \text { 208-218. }\end{array}$ http://dx.doi.org/10.1108/01443581011043591

APEC. (2000). Towards knowledge based economies in APEC. APEC Economic Committee.

APEC. (2004). Indicators of knowledge based economy. APEC Economic Committee.

Australia Bureau of Statistics (ABS). (2002). Measuring a knowledge-based economy and society - an Australian framework. Discussion paper (No. 1375.0).

Charnes, A., Clark, Charles T., Cooper, W. W., \& Boaz, G. (1985). A developmental study of data envelopment 
analysis in measuring the efficiency of maintenance units in the U.S. Air Forces. In Russell, G., \& Robert Thrall, G. (Eds.), Annals of Operations Research, 2(1), 95-11.

Charnes, A., Cooper, W. W., \& Rhodes, E. (1978). Measuring efficiency of decision making units. European Journal of Operational Research, 3, 429-44. http://dx.doi.org/10.1016/0377-2217(78)90138-8

Cooper, W. W., Seiford, L. M., \& Tone, K. (2000). Data Envelopment Analysis: A Comprehensive text with Models, Application, References, and DEA software (2nd ed.). New York: Springer.

Cubbin, J., \& Tzanidakis, G. (1998). Regression versus data envelopment analysis for efficiency measurement: an application to the England and Wales regulated water industry. Utilities Policy, 7(1998), 75-85. http://dx.doi.org/10.1016/S0957-1787(98)00007-1

Cullinane, K., Song, W. D., Ji, P., \& Wang, T. F. (2004). An application of DEA windows analysis to container port production efficiency. Review of Network Economics, 3(2). http://dx.doi.org/10.2202/1446-9022.1050

Delaimi, K. S. K., \& Ani, A. H. B. (2006). Using data envelopment analysis to measure cost efficiency with an application on Islamic banks. Scientific Journal of Administrative Development, 4, 142.

Farrell, R. M. (1957). The measurement of productive efficiency. Journal of the Royal Statistical Society, 120, 254-90. http://dx.doi.org/10.2307/2343100

Hemmasi A., Talaeipour M., Khademi- Eslam H., Farzipoor Sean R., \& Pourmousa S. H. (2011). Using DEA window analysis for performance evaluation of Iranian wood panels industry. African Journal of Agricultural Research, 6(7), 1802-1806.

Heng, T. M., Chin, T. H., \& Choo, A. (2002). Mapping Singapore's knowledge-based economy. Economic Survey of Singapore - (Third Quarter 2002).

Hsu, M., Luo, X., \& Chao, G. (2005). The fog of OECD and non-OECD country efficiency: a data envelopment analysis approach. In Johnston, T. C. (Ed.), Proceedings of the Annual Meeting of the association of collegiate marketing educators, March(1-5), 121-130.

Karahan, O. (2011). Input and output indicators of knowledge-based economy. $9^{\text {th }}$ international conference on knowledge, economy \& management proceedings, Sarajevo-Bosnia \&Herzegovina.

Lall, S. (2000). Export performance and competitiveness in the Philippines. QEH working paper 49, University of Oxford, UK.

Lo C. C. (2003). The diamond approach of national competitiveness using DEA and benchmarking analysis for Asian countries. Master's Thesis, Institute of Business Administration, National Cheng Kung University, Taiwan.

Norman, M., \& Stoker, B. (1991). Data Envelopment Analysis: The Assessment of Performance. Chichester: John Wiley \& Sons.

OECD. (1996). The knowledge-based economy. General distribution, OCDE/GD (96)102.

OECD. (2001). Science, Technology and Industry Scoreboard. Paris: OECD.

Park, J. L., Kim, S., Choi, S. Y., Kim, J. H., \& Kim, J. J. (2011). Measuring relative efficiency of Korean construction company using DEA/window. World Academy of Science, Engineering and Technology 60 2011.

Ramanathan, R. (2003). An Introduction to Data Envelopment Analysis a Tool for Performance Measurement. New Delhi: Sage Publications.

Scheel, H. (2000). Efficiency Measurement System. Retrieved from http://www.wiso.uni-dortmund.de/lsfg/or/scheel/ems/

Sufian, F. (2006). Trends in the efficiency of Singapore's commercial banking groups a non-stochastic frontier DEA window analysis approach. International Journal of Productivity and Performance Management, 56(2), 99-136. http://dx.doi.org/10.1108/17410400710722626

Sun, C. (2011). Assessing Taiwan financial holding companies' performance using window analysis and malmquist productivity index. African Journal of Business Management, 5(26), 10508-10523.

Tan, H. B., Hooy, C. W., Manzoni, A., \& Islam, S. M. N. (2008). Relative efficiency measures for the knowledge economies in the Asia Pacific region. Journal of modelling in management, 3(2), 111-124. http://dx.doi.org/10.1108/17465660810890108 
Tjakraatmadja, J. H. (2011). Knowledge sharing in the Indonesian context- institut teknologi Bandung (ITB) as potential knowledge hub to create value from academia, business and government linkages. In Menkhoff, T., Evers, H. D., Wah, C. Y., \& Fong, P. E. (Eds.), Beyond the knowledge trap- developing Asias's knowledge-based economies (pp. 276-277). Singapore: World Scientific Publishing.

World Bank Institute (WBI). (1999). World development report 1998/99: knowledge for development. Washington: World Bank.

World Competitiveness Yearbook (CD-ROM). (1995-2010). Switzerland: IMD.

World Development Indicators (WDI online). (1995-2010). Washington: World Bank. 